\title{
Influence of Environmental Factors in Hydrodynamic Modelling of Bacterial Distribution in Stormwater Ponds
}

\author{
F. Allafchi ${ }^{1}$, C. Valeo ${ }^{1 *}$, J. He$^{2}$, and N. F. Neumann ${ }^{3}$ \\ ${ }^{1}$ Department of Mechanical Engineering, University of Victoria, Victoria, BC V8W 2Y2, Canada \\ ${ }^{2}$ Department of Civil Engineering, Schulich School of Engineering, University of Calgary, Calgary, AB T2N 1N4, Canada \\ ${ }^{3}$ School of Public Health, University of Alberta, Edmonton, AB T4V 2R3, Canada
}

Received 06 May 2021; revised 17 June 2021; accepted 23 June 2021; published online 30 June 2021

\begin{abstract}
Due to the typically large sizes of many stormwater ponds, numerically modeling the bacteria fate and transport within these ponds is more practical than in situ monitoring. However, bacteria fate and transport models lack proper verification and rely on numerous assumptions without proper validation of these assumptions. In this paper, a sophisticated hydrodynamic model is developed for estimating bacteria levels in the Inverness stormwater pond, in Calgary, Alberta, Canada, and is verified in two ways. First, the bacteria concentrations predicted by the developed model for several locations within the pond were compared to data collected during two separate field campaigns at the pond. Good agreement was observed and while it was found that contamination increased over time between the two field campaigns, the most contaminated location was consistently in the west wing. Second, fluid flow velocity vectors in numerous locations were measured and compared with the modeled results. The impacts of model assumptions and inputs on the bacteria distribution in the pond were also assessed. The model was run for various particle-attachment rate and sizes, various rain hyetographs and various wind conditions. It was found that synthetic hyetographs can be used for design purposes to find the optimal location for withdrawal. The effect of wind direction was found to be event specific and location specific. In general, wind was found to play a crucial role in the bacteria distribution in the pond.
\end{abstract}

Keywords: stormwater ponds, water quality, hydrodynamic modeling, environmental hydraulics, computational fluid dynamics, hydrological model HEC-RAS, E. coli

\section{Introduction}

Reusing stormwater for overcoming water scarcity problems due to urbanization and climate change is becoming more prevalent in water resources management plans (He et al., 2008; Rodríguez-Sinobas et al., 2018). Stormwater may be considered an alternative resource for applications requiring less than pristine water quality; and therefore, stormwater retention ponds are the most viable sources of stormwater for large scale reuse (He et al., 2008). Several studies have been conducted regarding stormwater reuse (Zhang et al., 2015; National Academies of Sciences and Medicine, 2016; Goonetilleke et al., 2017; Hammes et al., 2018; Allafchi et al., 2019); however, pathogens in stormwater are still a source of public health concern (Mankad et al., 2019). Therefore, in most jurisdictions, the stormwater must meet local guidelines for water quality depending on the end-use. If reusing stormwater suggests that a potential exposure to bacteria and pathogens is possible, knowledge that guideline or regulation levels are never exceeded is necessary for reliable stormwater reuse. This knowledge is either ascertained through

\footnotetext{
${ }^{*}$ Corresponding author. Tel.: +1 250-721-8623; fax: +1 250-721-6051.

E-mail address: valeo@uvic.ca (C. Valeo).
}

ISSN: 2663-6859 print/2663-6867 online

(C) 2021 ISEIS All rights reserved. doi:10.3808/jeil.202100062. measurement or through modelling.

Assessing the bacteria and pathogen levels through measurement is often not practical for a variety of reasons including accessibility, spatial scale (physical size of the pond), and the variability in each of the multitude of environmental factors that may affect bacteria and pathogen levels over space and time. Therefore, computational models offer more practical solutions and studies have been developed to simulate bacteria fate and transport in large ponds with the intention of identifying the optimal location for water withdrawal (Allafchi et al., 2019, 2021).

Bacteria and pathogenic related water quality is often indicated through Fecal Indicator Bacteria (FIB) because FIB exist in abundance in warm-blooded animal intestines and are easily detected/measured (Borrego and Figueras, 1997). E. coli is the most common FIB and is currently used as a standard indicator bacteria (Tallon et al., 2005) for many jurisdictions. The source of FIB in stormwater ponds would arise from animal sources in the drainage area that are washed off, or added directly into the pond (from waterflow, for example).

The literature includes numerous models developed for simulating water quality of runoff from watersheds (Shrestha and Wang, 2019; Vanaei et al., 2021) including the fate and transport of FIBs in watersheds. These models generally involve integrating a hydrological model with a bacteria fate model (de 
Brauwere et al., 2014a) and are primarily 1-dimensional for a variety of reasons including data availability issues (Aguilera et al., 2016). They can provide a low-cost approach to simulating bacteria fate and transport over large areas where only one dimension or only one direction is a reasonable assumption in the modelling. Water quality modelling of water bodies like stormwater ponds requires the additional integration of hydrodynamic concepts. Hydrodynamics is used in many studies of water quality in water bodies, but many are 1- or 2-dimensional treatments (Zheng et al., 2011; Babaeyan-Koopaei et al., 2003; Wang et al., 2016) that may involve large uncertainties depending on the circumstances.

There are a handful of 3-dimensional models that use Computational Fluid Dynamics (CFD) for simulating bacteria in water bodies. CFD models have been shown to be capable of determining spatial and temporal bacteria concentration in large water bodies such as stormwater ponds (Allafchi et al., 2019). While computationally expensive, they are sophisticated modelling systems that can provide a wider array of outcomes and possibilities for engineering design, while avoiding the inaccuracies of 1- and 2-dimensional treatments to real-world applications. A CFD model was developed to simulate the fate of $E$. coli in a stormwater pond arising from a variety of processes including attachment and settling (Vergeynst et al., 2012). The authors assumed that there was no convection and the importance of attachment in the bacterial decay process was highlighted. Shilton and Mara (2005) modelled the transport of $E$. coli in large waste stabilization ponds with different configurations using a 3-dimensional CFD model that incorporated a first order decay model (a commonly used fate model). The model focused on the bacteria concentration in the inlet and outlet and implemented a bacteria decay model according to the residence time calculated by the CFD. Similarly, fecal coliform levels in various waste stabilization ponds were also simulated using 3 dimensional CFD models (Shilton, 2000; Shilton and Harrison, 2003; Shilton et al. 2008), thus, highlighting the capability of CFD models for simulating fate and transport of bacteria. $\mathrm{Wu}$ and Chen (2011) also incorporated a first order kinetic decay model in a 3-dimensional CFD model to simulate biological oxygen demand (BOD) in an anaerobic lagoon with good success.

While the movement of water in medium sized water bodies is observed to be inherently wind driven (Abbasi et al., 2016), all of the above mentioned studies neglected wind effects. Moreover, all of the transport models assumed steady state conditions, which may only be appropriate in a few circumstances. In most real-world situations, conditions are rarely steady state. Allafchi et al. (2021) developed an integrated hydrological-CFD model (IHCFD) to simulate bacteria fate and transport in the Inverness stormwater pond, in Calgary, Alberta, Canada, that incorporated wind and unsteady conditions. The model had two components: a hydrological component and a CFD component. The hydrological component calculated the stormwater runoff discharging into the pond from the catchment, which provided inputs to the CFD model to simulate the bacteria in the pond in three dimensions. The model was also used to find the optimal location for water withdrawal for reuse.

There are two main challenges associated with the models simulating bacteria fate and transport. First, as it is highlighted in previous studies (de Brauwere et al., 2014a; Allafchi et al., 2019), due to a lack of data, model verification is very challenging and thus, often neglected. Second, modeling fate and transport is a highly parameterized endeavour, and due to the general lack of information on all these parameters, numerous assumptions are made in order to develop a functioning model. These assumptions, if left invalidated, lead to inherent uncertainty in the output. In this paper, both of the aforementioned problems are considered in the further development of the IHCFD model. The IHCFD was modified in this work by adding a non-settling particulate-attached bacteria concept, introduceing alternate attachment rates and varying sediment sizes. This modified IHCFD model was verified using bacteria concentra- tion data and fluid flow data (Allafchi et al., 2020) collected in a variety of locations spatially and with depth, that were compared with those data predicted by the model at these locations. In addition, the impact of several important assumptions made in IHCFD on bacteria distribution were studied. Moreover, in an attempt to decrease dependability on on-site collected data for design purposes, the model's capacity to provide a reasonable bacteria distribution without actual data was also studied.

\section{Methodology}

\subsection{Study Site}

The Inverness stormwater pond is a T-shaped, large urban stormwater pond located in a residential area in the Southeast quadrant of the City of Calgary. On average, it is approximately three meters deep and has seven inlets and two outlets (see Figure 1). The inlets discharge stormwater runoff from a catchment that is approximately 415 ha in surface area.

\subsubsection{Data Collection Campaigns}

A wide variety of data have been collected at the study site over a near 15 year period (He et al., 2008, 2010a, 2010b, 2011a, 2011b; He et al., 2015; Allafchi et al., 2019, 2021; Allafchi et al., 2020) primarily during the irrigation seasons. Data were collected in the pond in 2004 to 2007, 2017, 2018 and 2020 through surface grab samples, stormwater runoff samples, on-site meteorological data and flow field velocity measurements. The surface grab samples were collected from the pond in a depth equal to $10 \sim 20 \mathrm{~cm}$ below the surface. They were collected from 6 sampling locations during between 2004 and 2007 and this sampling was repeated for 4 locations in 2017. The locations in the first sampling campaign were selected to be greater in number and distribution throughout the pond because the goal was to understand bacteria distribution in the pond, and to identify the optimal location for water withdrawal. However, the second sampling campaign was aimed to further verify the model regarding the developments in the catchment between 2007 and 2017. Therefore, the samples were collected from a fewer number of locations in the second campaign. Figure 2 shows the grab sampling locations. Samples were tested for several water quality indicators including E. coli. The data was collected in 26 and 24 days during the first and second campaign, respectively, with no attempt to favor rainy or dry days. The stormwater 


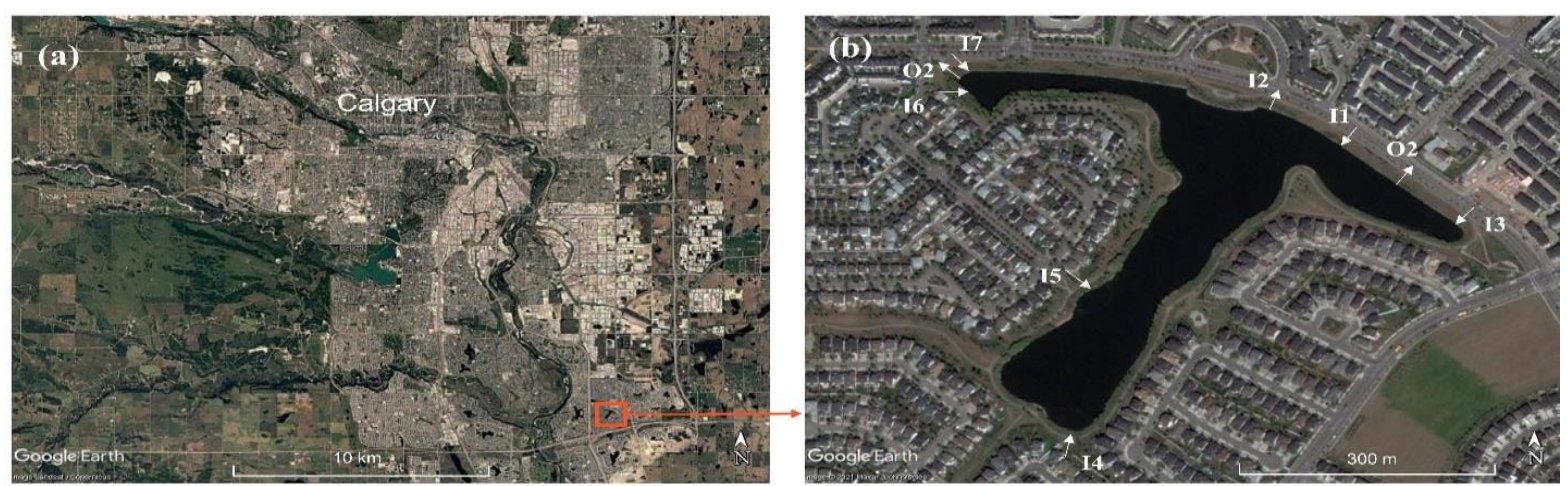

Figure 1. The study site: (a) aerial view of the City of Calgary; and (b) the locations of inlets (I1 I7), outlets (O1 and O2) $\left(50^{\circ} 54^{\prime} 40.07^{\prime \prime} \mathrm{N} 113^{\circ} 57^{\prime} 45.18^{\prime \prime} \mathrm{W}\right.$ at the centre of the map).
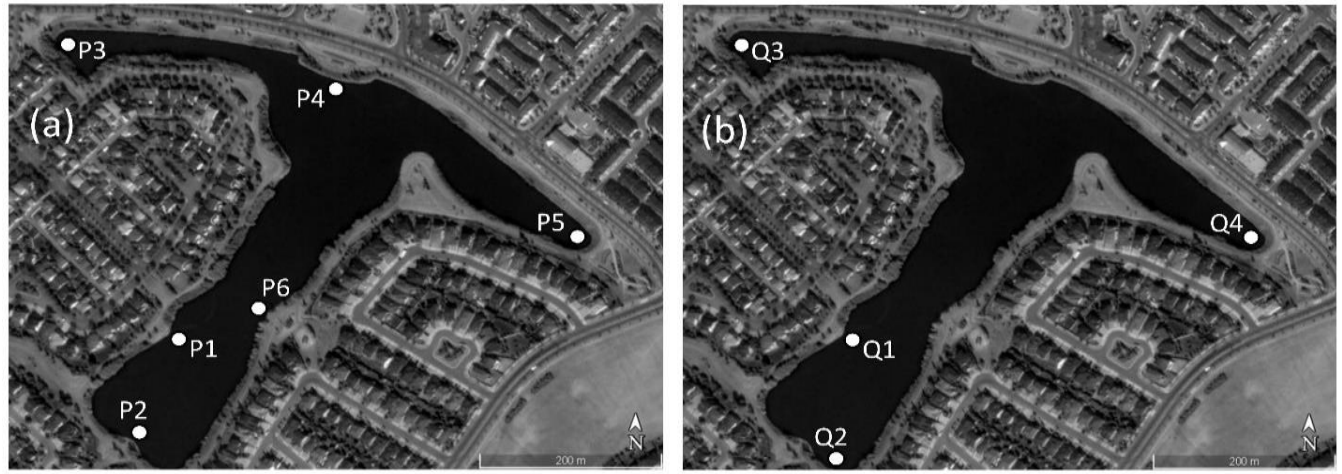

Figure 2. Grab sampling locations for the data collection campaigns performed in (a) 2004 to 2007; and (b) 2017.

runoff sampling included flowrate and E. coli concentration. To be specific, flowrates of inlet $\mathrm{I} 5$ and outlet $\mathrm{O} 2$ were measured at a 5-minute interval. In addition, an autosampler, triggered by a rain gauge, was placed in a manhole before the inlet 15 in order to measure E. coli concentrations. The stormwater runoff sampling scheme was scheduled to collect more samples (namely at shorter time intervals) in the beginning of the events in order to catch the first flush effect. The meteorological data includes 5-minute rain data in a time period between 2004 and 2007 as well as 5-minute wind data collected on August 29, 2020. Flow field velocity data were also collected from multiple locations in the pond in 2020. Further details on the collection and use of these data for verifying the IHCFD model components are given below.

\subsection{Hydrological and Hydrodynamic Bacteria Fate and Transport Modelling}

The developed model has three components: a hydrological component, a CFD component, and a bacteria fate component. The first two are applied through software, while the third is embedded in the CFD component through a variety of assumptions.

\subsubsection{Hydrological Model}

The hydrological component involves HEC-HMS (U.S.
Army Corps of Engineers, 2016) model, which calculates stormwater runoff using the Soil Conservation Service Curve Number method based on land-use data. HEC-HMS was previously calibrated and verified for the drainage catchment to the pond (Allafchi et al. 2019) using data in the field campaigns that took place from 2004 to 2007 . This component provides stormwater runoff generated by the catchment's subbasins transported through the inlets of the pond as input to the CFD component.

\subsubsection{CFD Model}

The CFD model with inputs from the hydrological model simulates pond hydrodynamics leading to a simulated bacterial distribution in the pond. For this purpose, conservation equations are numerically solved where the equations are discretized over a grid that is generated according to the Fractional Area/Volume method (FAVOR ${ }^{\mathrm{TM}}$ ), which enables the equations to recognize the boundaries without the need to necessarily make a body-fitted grid. Equation 1 shows the conservation of mass, in FAVOR (Savage and Johnson, 2001):

$\frac{\partial\left(u_{j} A_{j}\right)}{\partial\left(x_{j}\right)}=\frac{R_{s}}{\rho}$

where $j=1,2,3$ indicates the three directions of 3D domains; $u_{j}$ and $A_{j}$ are the velocity and the fractional area open to flow in 
the three directions, respectively; $R_{s}$ is a mass source term; and $\rho$ is the density of the fluid. Equation 2 shows Reynolds-Averaged Navier Stokes equation (RANS), which represents the conservation of momentum:

$$
\frac{\partial u_{t}}{\partial t}+\frac{1}{V_{F}}\left(u_{j} A_{j} \frac{\partial u_{t}}{\partial x_{j}}\right)=-\frac{\partial P}{\rho \partial x_{k}}+G_{k}+f_{k}-\frac{R_{s}}{\rho V_{F}}\left(u_{k}-u_{s k}\right)
$$

where $t$ is the time; $k=1,2,3$ indicate different directions; $V_{F}$ is the fractional volume open to flow; $P$ is pressure; $G_{k}$ is the body force; $u_{s k}$ is the injection velocity of fluid; and $f_{k}$ represents viscous stresses for which a turbulence model is required for closure. The renormalized group $k-\varepsilon$ turbulence model is used for modeling the turbulence.

The free surface is tracked by solving the Volume of Fluid (VOF) equation, Equation 3 (Hirt and Nichols, 1981):

$$
\frac{\partial F}{\partial t}+\frac{1}{V_{F}}\left(\frac{\partial}{\partial x_{j}}\left(F A_{j} u_{j}\right)\right)=0
$$

where $F$ represents the fraction of cell filled with fluid. Using the Finite Volume Method, the equations are discretized over an orthogonal structured grid which has over 4 million meshes. A 3-dimensional sketch of the pond was generated using AutoCAD Civil 3D based on bathymetric data that was collected during a survey performed on August 30, 2016. The equations are solved for unsteady state in the time period from half an hour before the start of the rain events to 24 hours after the end of the events. The time step is determined to keep the Courant number less than unity (Flow Science, 2018), but not to exceed $0.25 \mathrm{~s}$.

The inlets are modelled with disk-shaped mass and momentum sources, for which the input values are obtained from the hydrological component as noted earlier. The hourly wind data was obtained from the meteorological station at the Calgary International Airport. The wind is modeled as shear stress acting on the top layer of the grid using Equation 4:

$\tau=\rho_{\text {air }} C_{D}|\vec{W}| \vec{W}$

where $\tau$ is the shear stress; $\rho_{\text {air }}$ is the density of the air; $\vec{W}$ is the wind vector; and $C_{D}$ is the drag coefficient, which is 0.0026 (Foreman and Emeis, 2010) in the model.

\subsubsection{Bacteria Transport}

The transport of bacteria heavily depends on attachment. Regarding the transport of bacteria, three types of bacteria, including free-floating bacteria, settling particulate-attached and non-settling particulate attached bacteria, were used in this study. It was assumed that the biological movement of bacteria is negligible and that the bacteria have a negligible effect on the flow field. Thus, the free-floating bacteria move with the water and are modeled as a passive scalar. The non-settling particulateattached bacteria transport is similar to that of free-floating.
However, their fate is different from the free-floating. Both the free-floating and non-settling particulate-attached bacteria transport are modeled using equation 5:

$$
\frac{\partial F_{b}}{\partial t}=\frac{1}{V_{F}}\left(u_{j} A_{j} \frac{\partial F_{b}}{\partial x_{j}}\right)=\frac{1}{V_{F}}\left[\frac{\partial}{\partial x_{j}}\left(A_{j} D \frac{\partial F_{b}}{\partial x_{J}}\right)\right]+F_{b}^{\text {sor }}
$$

where $F_{b}$ is bacteria concentration, $D$ is diffusivity and $F_{b}{ }^{\text {sor }}$ is the bacteria source term. Similar to previous studies (Wu and Chen, 2011; Allafchi et al., 2019), it was assumed that the diffusion of bacteria is negligible compared to convection.

A sediment transport model was integrated into the main model in order to simulate the transport of settling particulateattached bacteria. All types of the aforementioned bacteria are transported with the fluid flow, with an exception of the settling particle attached bacteria that settle once following the fluid flow. In other words, that type of bacteria has an extra component of velocity downward. Equation 6 shows the downward component of velocity related to the settling particulate-attached bacteria:

$u_{\text {settling }}=\frac{v_{f}}{d}\left[\left(10.36^{2}+1.049 d_{*}^{3}\right)^{0.5}-10.36\right]$

with $d^{*}$ equal to the dimensionless grain diameter. According to the City of Calgary (The City of Calgary Water Resources, 2011), stormwater runoff of the region carries a wide range of sediment size. However, it was assumed that E.coli attach to particles smaller than $2 \mu \mathrm{m}$ (Muirhead et al., 2006). Similar to previous studies (Bai and Lung, 2005; Wu et al., 2009; Allafchi et al., 2019), it was assumed that half of the bacteria are attached to sediment particles.

\subsubsection{Bacteria Fate Model}

Once the transport of both free-floating and particulateattached bacteria is determined, a field function implements the first order decay of bacteria on them separately and calculates the total number of bacteria in each computational cell. Similar to previous studies (Wu et al., 2009), it was assumed that the decay rate of the attached bacteria is a quarter of that of freefloating bacteria.

Equation 7 shows the first order kinetic decay:

$C_{t}=C_{0} e^{(-\eta t)}$

where $C_{t}$ and $C_{0}$ are the concentration of bacteria at the time of $t$ and $t=0$, respectively; and $\eta$ is the bacteria decay rate. The temperature is the dominant parameter affecting survival of bacteria (Wang et al., 2018). The decay rate of free-floating E.coli is modelled by Equation 8, which has been used in many studies (Beaudeau et al., 2001; Ouattara et al., 2013; de Brauwere et al., 2014b):

$\eta_{E . c o l i}=k_{20} e^{\left[-\frac{(T-25)^{2}}{400}\right]} / e^{\left[-\frac{25}{400}\right]}$ 
where $k_{20}$ is decay rate of E.coli at $20^{\circ} \mathrm{C}$. In this paper, similar to Ouattara et al. (2013), a value of $1.25 \times 10^{-5}$ is used for $k_{20}$.
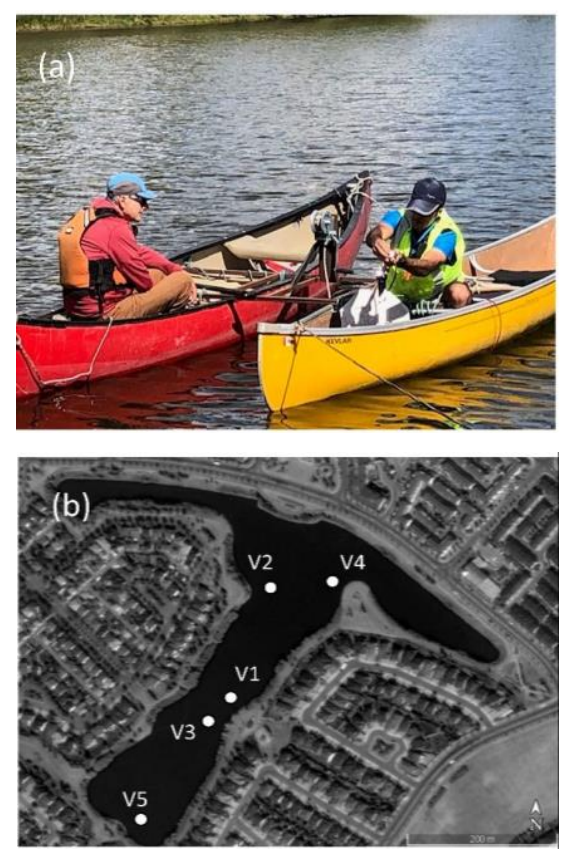

Figure 3. Data collection on August 29, 2020: (a) canoe setup; and (b) data collection locations (the aerial map was acquired from Google earth).

\subsection{CFD Model Verification Data}

Specific details on what data were used, and how, to verify the IHCFD model's velocity flow field and predicted bacteria concentrations are given below.

\subsubsection{Flow Field Velocity Data}

On August 29, 2020, flow field velocity magnitudes and directions were measured in multiple locations within the pond from two canoes deployed near the centre of the pond. Figure 3 shows the canoe setup and locations where the data were collected. At each location, the canoes were secured using 4 anchors and a weight was send to the bottom with a winch held between the boats. Also, specific attention was paid to position the canoes in the wind direction in order to minimize the impact of the canoes on the flow near the data collection locations. The data were collected at different depths and with two instruments: an Acoustic Doppler Velocity meter (ADV) and a Dye Injection Velocity meter (DIV) (Allafchi et al., 2020). However, due to the limitations in the devices, in some locations the data were acquired with only one instrument. The ADV cable did not allow measurements deeper than $1.8 \mathrm{~m}$. In addition, DIV had limitations in measuring flow field velocity when in very low speeds (Allafchi et al., 2020). The wind driven flow field in the pond was simulated using the wind data collected from a meteorological station installed on the Northwest side of the pond. The collected data and the simulation results were compared for the purpose of model verification. The flow field was measured at
V1 on August 27, 2020; however, the meteorological station was not working properly on that day. Therefore, the data on that location was not used for the verification.

\subsubsection{Bacteria Concentration Data}

The bacteria concentration in the inlet I5 was measured during several storm events in 2007 . The bacteria concentration in the other inlets was obtained based on the land-use in other subbasins and by knowing the relationship between the landuse and concentration of bacteria in the stormwater (Schoonover and Lockaby, 2006). TSS were also measured during the data collection campaign. TSS of other inflows was assumed to be the same as that of I5. In addition to the data collected from the I5 inlet, E. coli data from weekly grab samples data collected from $10 \sim 20 \mathrm{~cm}$ below the surface in six locations inside the pond (P1 P6 in Figure 2) in 2007 were also used E.coli data collected in 2017 from the four locations sampled that year were also used.

\subsection{Verification and Assessment Methods}

A sensitivity analysis was conducted to assess the assumptions used in the model. The Basis of Comparison (BOC) from which the sensitivity analysis was made is from three storm events: one on September 20, 2007; another on May 28, 2007; and the third on August 26, 2007. The IHCFD model was setup to simulate the pond's response and resulting bacterial distribution during and after each of these storms, which served as the BOC. The impact of some of the model assumptions on the bacteria distribution was assessed through the sensitivity of bacteria concentrations at 7 locations (the six locations P1 to P6 and the withdrawal location) by modifying specific model assumptions and comparing the results to that of the BOC. To be specific, bacteria distribution in the 7 locations after the events were computed for different assumptions of: (i) attachment rate of bacteria; (ii) sediment particle size that the bacteria attach to; (iii) rain hyetograph; (iv) wind direction; and (v) wind magnitude. As well, a sixth set of simulations involved determining the average wind during the irrigation season and the simulations were run with that wind in order to assess the predictability of the bacteria distribution during average wind and zero wind conditions. The time period of the simulations was half an hour before the start of the events until 24 hours after the end of events. Irrigation is generally unnecessary during and right after (e.g., within 24 hours) rain events. Therefore, the bacteria distribution in the pond 24 hours after the end of the events, when possibly starting irrigation, was of interest. Herein, the term "after event" refers to 24 hours after the end of the event. Numerous simulations were run for this paper, however, particular attention was paid to change only one assumption/input at a time.

The attachment study was performed only for the event on September 20, 2007. However, the other assumptions were assessed for all of the three events. Attachment to four particle sizes was simulated and the distribution of bacteria in the pond was obtained. In addition, bacteria distribution was found for 3 different attachment rates, namely 25, 50 and $75 \%$. The impact 

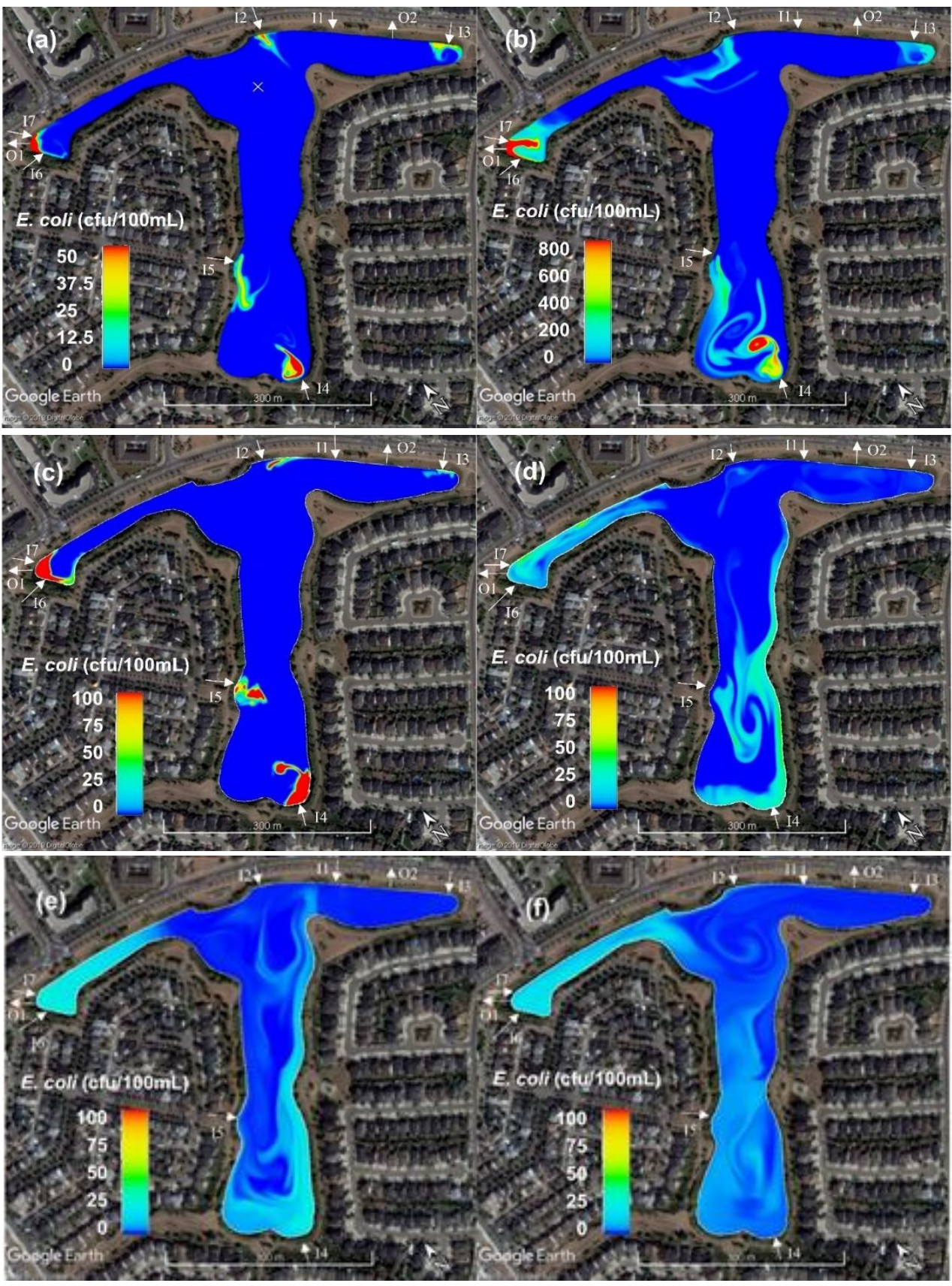

Figure 4. Modeled E.coli concentration on the surface of Inverness pond on (a) May 28, 2007 at 1:05 am (end of storm event); (b) August 26, 2007 at 3:20 pm (end of storm event); (c) September 20, 2007 at 9:40 pm (end of storm event); (d) September 21, 2007 at 3:40 am; (e) September 21, 2007 at 3:40 pm; and (f) September 21, 2007 at 9:40 pm. Note the difference in the color bars and the withdrawal location is shown by a white cross sign in Figure 4(a).

of rain was also assessed by generating four synthetic hyetographs for each event and then run the model in order to find the bacteria distribution after the events. Comparing the resultant bacteria distribution with that of the actual rain would provide insight into the role of rainfall patterns on the predictability of bacteria distribution in the pond. Also, a comprehensive assessment was performed to find the impact of wind on the bacteria distribution. The actual wind, which changed direction and magnitude every hour (according to the data), was rotated from -90 to +90 degrees. To be specific, the actual event's wind magnitude was left untouched, however, all of the wind direction data points were shifted by a constant value. During the study of wind, rain hyetographs, attachment rate and all other settings remained the same as those of the BOC. It should be noted that the studies on the rain and wind were performed introducing a non-settling sediment, for which the decay of particulate-attached 
bacteria was taken into account, but the settling was neglected. This type of sediment was used in the aforementioned studies due to the high numerical costs associated with the sediment transport models. Using a non-settling sediment type made it practical to run the copious number of simulations. Similarly, to assess the assumptions and impacts of wind magnitude, only the wind's magnitude was changed while all other assumptions and inputs remained unchanged. The wind magnitude data, which are separate data points, was changed by $\pm 25 \%, \pm 50 \%, \pm 75 \%$ and $100 \%$. The process was performed for all of the three storm events. In other words, the wind blowing over the pond during each event was changed and its impact on the bacteria distribution was found if the wind was stronger or weaker. Finally, with regard to average wind conditions, the recorded wind data in the region was obtained and the wind during the irrigation season was averaged. Wind magnitude data since 1971 and wind direction data since 2014 were obtained (Canada Weather Stats, 2020) and the average was calculated. The events were simulated with the average wind as well as \pm 1 standard deviation of the average wind. This set of simulations was performed to assess the predictability of bacteria distribution without having the wind data of the event. The simulations were performed using FLOW-3D 12u1 CFD commercial code. The simulations were run on 3 nodes, equal to 128 computational cores, of Cedar, which is a high-performance computer run by Compute Canada.

\section{Results and Discussion}

Figure 4 shows the bacteria distribution on the surface of the pond at the end of storm events on 28 May 2007 and $26 \mathrm{Au}-$ gust 2007 as well as during 24 hours after the end of the event that occurred on September 20,2007. The highly contaminated stormwater was discharged into the pond through the inlets and distributed throughout the pond. In Figures 4(c) to 4(f), it can be seen that even after 24 hours from the onset of the event, bacteria were not evenly distributed through the pond, and some parts of the pond were more contaminated than other parts. The middle of the pond near the surface, where the three wings join, was already determined as the optimal location for withdrawal for reuse because it has the lowest concentration of bacteria, comparatively (Allafchi et al., 2021). The withdrawal location is shown by a cross sign in Figure 4(a).

\subsection{Verification of Flow Velocity Vectors}

The important role of fluid flow field in the hydro-environmental models was previously emphasized (Allafchi et al., 2019). Therefore, in an attempt to validate the model with respect to fluid flow field, velocity data were collected from the pond and the model was run for the same day. Figure 5 demonstrates the collected data from the pond as well as the simulation results for the corresponding day. The model slightly underestimated velocity magnitude. It might be associated with the wind tunnel effect due to the trees and buildings around the pond which can increase wind velocity over the pond, particularly over the South wing. On the other hand, wind obstruction by the buildings might have caused underestimation of wind by the on-site meteorological station. In general, good agreement was observed for both velocity magnitude and direction. The deviation of the simulated flow direction from measured flow direction is relatively high in three locations, including V2 and V3 at a depth equal to $2.6 \mathrm{~m}$ and $\mathrm{V} 4$ at a depth equal to $0.3 \mathrm{~m}$. At these locations, the measurements are associated with high random error because the flow velocity is comparatively low, in which even small eddies could change the flow direction (Allafchi et al., 2020). The flow near the surface at V2 and V3 were in nearly opposite directions to the directions at these locations near the bottom. It suggests that the circulation of the wind-driven flow in the pond was reasonably approximated by the model.
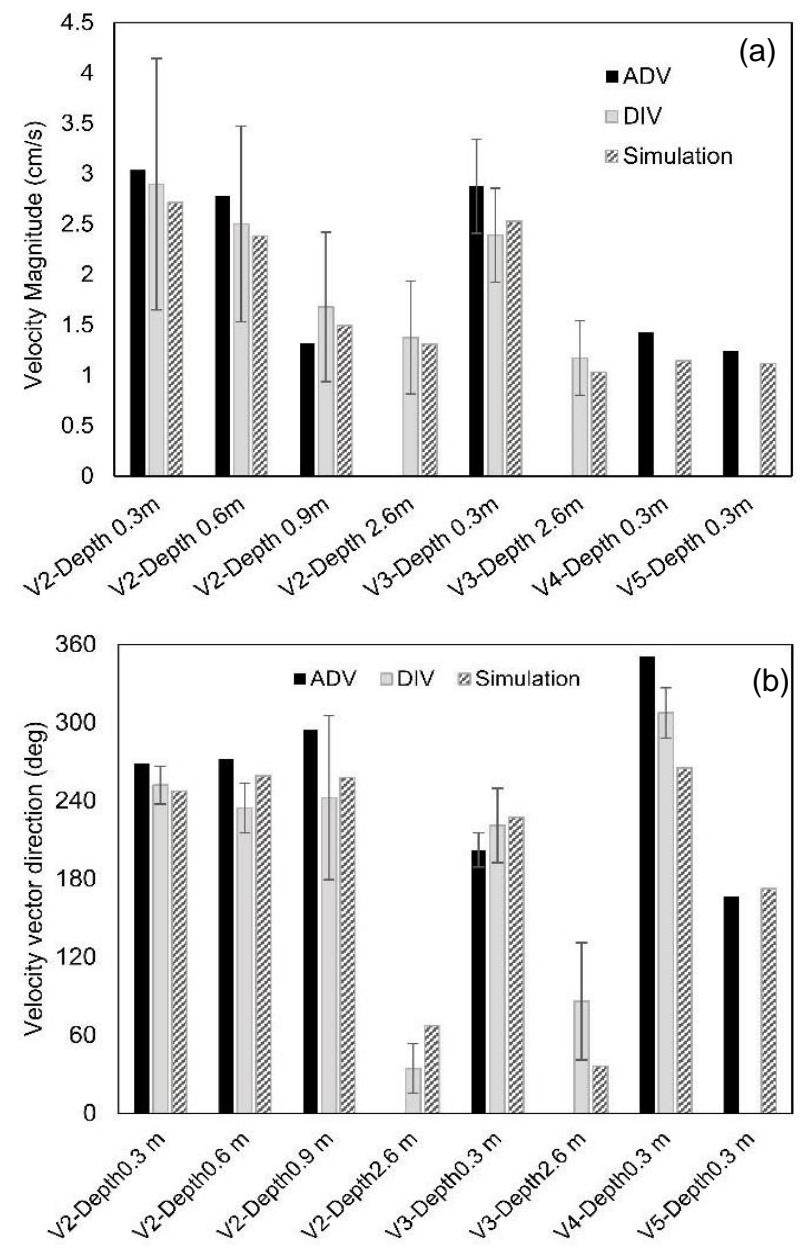

Figure 5. Comparison of simulation results with observations on August 29, 2020, (a) flow velocity magnitude; and (b) flow direction.

\subsection{Verification of Bacteria Distribution}

It should be noted that the bacteria data collected in the pond in 2007 were collected over a period of 26 days with no attempt to favour rainy or dry days; however, 7 out of the 26 days happened to be within three days after a rain event. In addition, during another campaign in 2017, similar data was collected in 24 days but from four different locations in the pond. Similarly, 6 and 4 days were within two and one days after a storm event, respectively. 

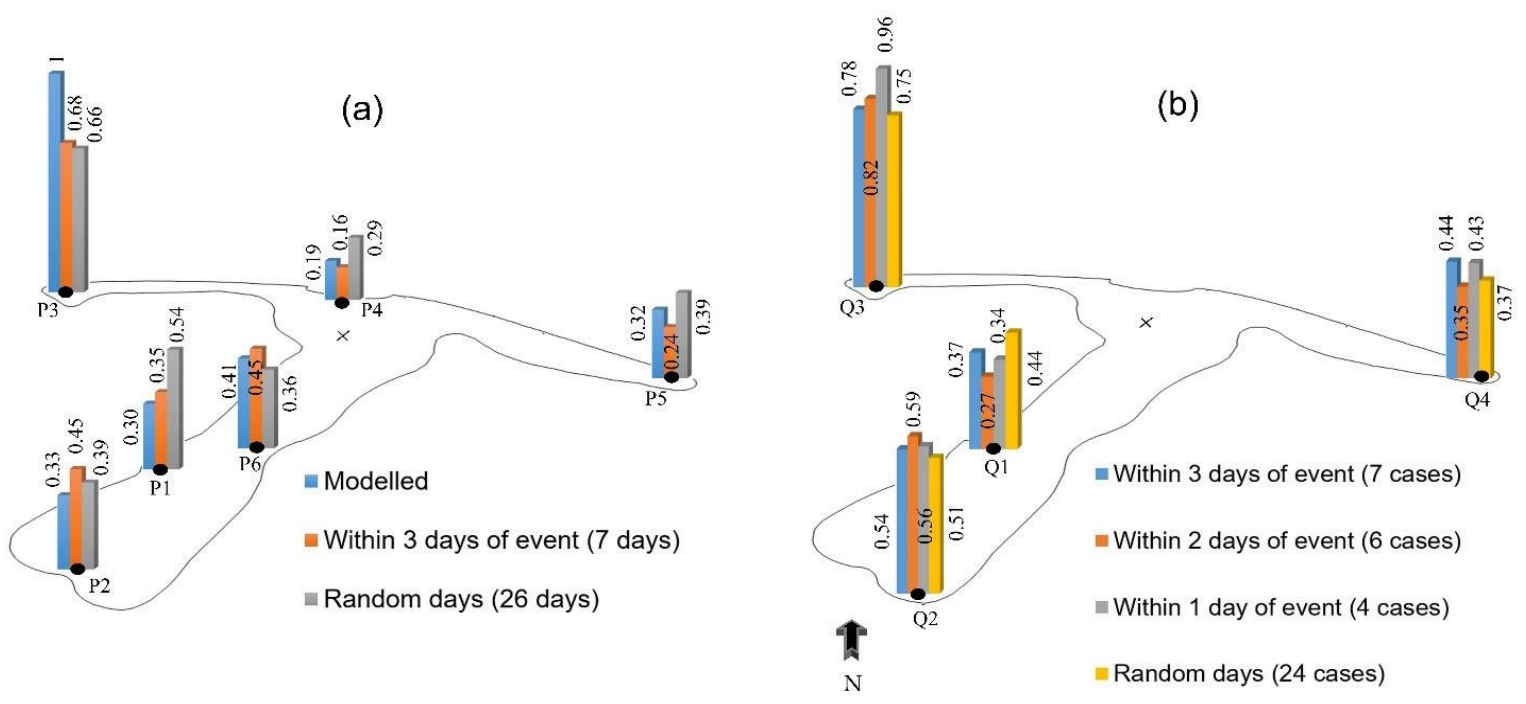

Figure 6. Normalized E. coli at the Inverness pond; data collected during the campaign in (a) 2007; and (b) 2017.

The E. coli concentrations were normalized by dividing the observed concentration by the maximum concentration observed in all locations for the day. For example, the location that has the maximum E.coli concentration would have a normalized $E$. coli equal to one. The normalized E.coli at each location was averaged for each category separately. The simulated bacteria concentration was also normalized with a similar approach. Figures 6(a) and 6(b) show the normalized bacteria collected in the first and second campaign, respectively. In spite of the change that occurred in the land-use between the year 2007 and 2017, the most contaminated part of the pond did not change. The data collected from both campaigns shows that the tip of the West Wing had the highest concentration of bacteria compared to the other locations. Figure 6(b) demonstrates that after rain events, the tip of the West wing was likely the most contaminated part of the pond. However, in a few days after the events, some of the pollution at this location was transported to the rest of the pond. Following the West wing, the South wing was the second most contaminated wing of the pond. Comparing Figures 6(a) with 6(b), both of the South and East wings became slightly more contaminated during the time between 2007 to 2017 , particularly after rain events. The reason might be the developments (turning farms into residential areas) during that time on the East and South side of the catchment from which the stormwater drains into the pond through I 3 and I4, respectively.

\subsection{Impact of Model Assumptions}

\subsubsection{Impact of Bacteria Attachment Assumptions}

In the model developed for the pond, it was assumed that half of the bacteria attach to sediment particles. To be specific, half of the E.coli were assumed to be attached to particles smaller than $2 \mu \mathrm{m}$, as Muirhead et al (2006) found. It should be noted that other particle sizes, which E.coli predominantly attach to, were also proposed in the literature. For example, Anna et al., (2005) found that more than $90 \%$ of E. coli attach to particles smaller than $30 \mu \mathrm{m}$ (Anna et al., 2005). The impact of both as- sumptions, namely the attachment ratio and particle size, on the bacteria distribution in the pond was studied. Figure 7 shows the impact of attached particle size on the bacteria concentration at the withdrawal and the six locations. In general, changing the particle size did not change the relative distribution of bacteria. In other words, the most and the least contaminated locations and the ones in between did not change. However, increasing the particle size decreases bacteria concentration near the surface. The change is quite substantial replacing sediment size smaller than $2 \mu \mathrm{m}$ with 2 to $10 \mu \mathrm{m}$. However, the change in bacteria concentration was negligible when the particle size was increased from $10 \sim 20 \mu \mathrm{m}$ to $20 \sim 50 \mu \mathrm{m}$. The reason is that settling of particles that are smaller than $2 \mu \mathrm{m}$ was not considerable (Allafchi et al., 2019), but larger particle sizes are associated with more settling which decreases bacteria concentration in the study locations that are situated near water surface. On the other hand, reduction in bacteria concentration by increasing the particle size occurred only to an extent. Once most of the attached bacteria are already settled, increasing attached particle size does not further decrease bacteria concentration. This can be observed comparing the bacteria concentration for the attached particle of $10 \sim 20 \mu \mathrm{m}$ and $20 \sim 50 \mu \mathrm{m}$.

\subsubsection{Impacts of Settling Sediment}

In addition, the attachment rate was studied and in this study, it was assumed that E.coli attach to particles smaller than $2 \mu \mathrm{m}$. Since the settling of such particles is found to not be considerable (comparatively speaking), two sediment types were considered for this study, namely sediment with settling and sediment without settling. The results from the two sediment types are shown in Figure 8. The sediment with settling was modeled integrating the sediment transport model into the main model; however, sediment without settling was modeled with passive scalars. In both cases bacteria concentration reduced with decreasing attachment rate at P3, the most contaminated location. Figure 8(b), which is associated with the non-settling 
sediment type, shows that decreasing the attachment rate decreases the bacteria concentration in all of the locations. However, in the settling-sediment type, bacteria concentrations were not necessarily decreased by reducing attachment rate (see Figure 8(a)). Attachment protects bacteria from some lethal environmental factors, and thus, decreases the decay rate. That explains why in the non-settling sediment type, decreasing attachment rate decreases bacteria concentration. However, it is harder to predict the change in bacteria distribution with settling-type sediment because the effect of settling and the effect of protection on the changes in bacteria concentration effectively neutralize each other. However, in the settling type sediment, the bacteria concentration reduced by decreasing attachment rate only at P3 and remained nearly the same at other locations. The passive scalar model used for non-settling sediment, requires much less numerical time compared to the sediment transport model. Therefore, it became practical to further conduct the sensitivity analyses on the factors influencing the bacteria distribution in the pond, particularly factors that the attachment does not play a role in, such as wind and inlet flowrates. Hence, the case with 50\% attachment to the non-settling sediment is used as part of the BOC benchmark in the rest of this paper to run the model numerous times that study the effect of multiple factors on the bacteria distribution.

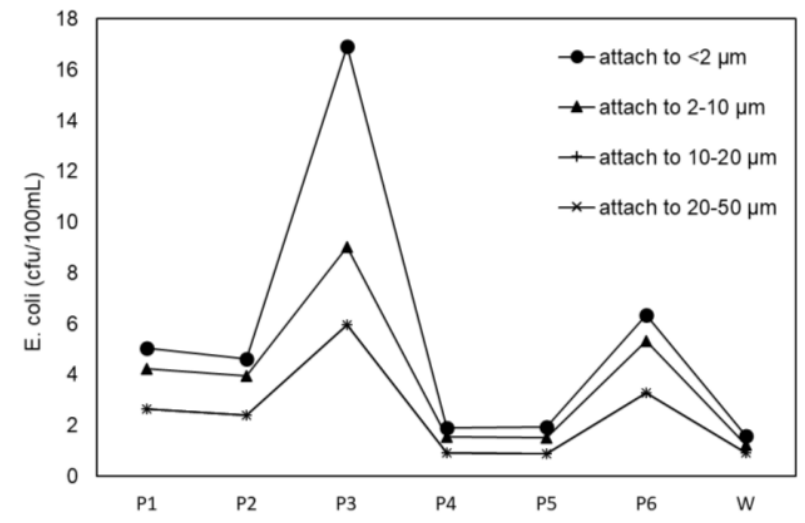

Figure 7. Impact of particle size attachment on bacteria distribution after the event on September 20, 2007. The 'W' on the horizontal axis refers to the withdrawal location.

\subsubsection{Impact of Rain Distribution and Flowrate}

In order to find the impact of inflow flow rates on the distribution of bacteria, four synthetic rains were generated and fed to the hydrological model. Three Chicago hyetographs (American Iron and Steel Institute, 2010) and a triangular hyetograph (Ellouze et al., 2009) was modeled and the resultant bacteria distributions were compared with that of the actual event. The Chicago hyetographs are distinguished by the peak factor varying from 0.3 to 0.5 . The synthetic hyetographs were designed to have the same total volume and duration of rain compared to the actual events. They were also set to occur at the same time as the actual event. Figure 9 demonstrates the synthetic hyetographs generated for the event occurring on September 20, 2007.
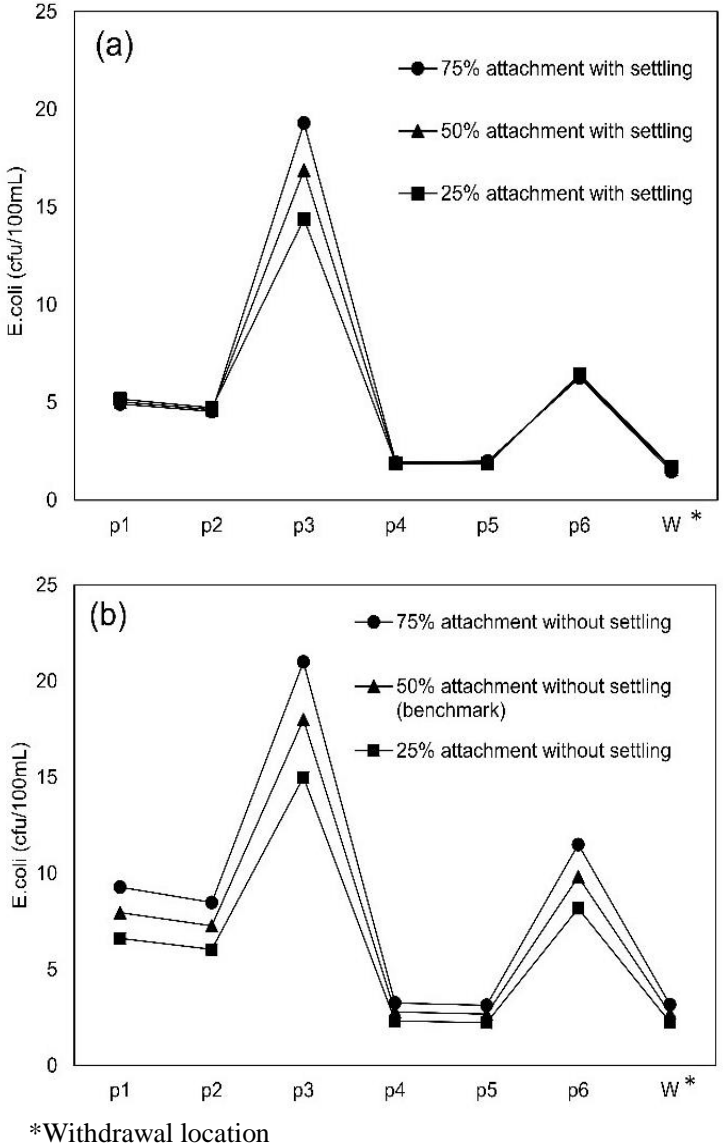

Figure 8. Impact of attachment rate on E.coli distribution for (a) sediment with settling; and (b) sediment without settling. The ' $\mathrm{W}$ ' on the horizontal axis refers to the withdrawal location.

Once the flowrates were found running the hydrological model, the CFD model was run to find the bacteria distribution under different rain conditions. All other settings and conditions including bacteria pollutographs of the inlets and wind at each day was the same as the actual event day. The distribution of bacteria in the six locations using the synthetic hyetographs was obtained and compared to that of the BOC for each of the three events (see Figure 10). In almost all of the cases, the bacteria concentration was underestimated. However, the most contaminated location of the pond, P3, did not change by altering the hyetograph in any of the events. It is to be expected that the total number of bacteria changes with changing hyetograph because the bacteria pollutograph, of the inlets did not change during this study. Therefore, depending on the timing of pollutograph and flowrate peaks, the total number of bacteria in the pond can be overestimated or underestimated. In addition, the pattern of bacteria concentration from P1 to P6 was almost repeated with all of the hyetographs. Only the triangular hyetograph on September 20, 2007 showed a slightly different pattern. Moreover, the withdrawal location appeared to be the least contaminated location of the pond even with different hyetographs. The concentration of bacteria at only the withdrawal location with different hyetographs is shown in Figure 11. This 

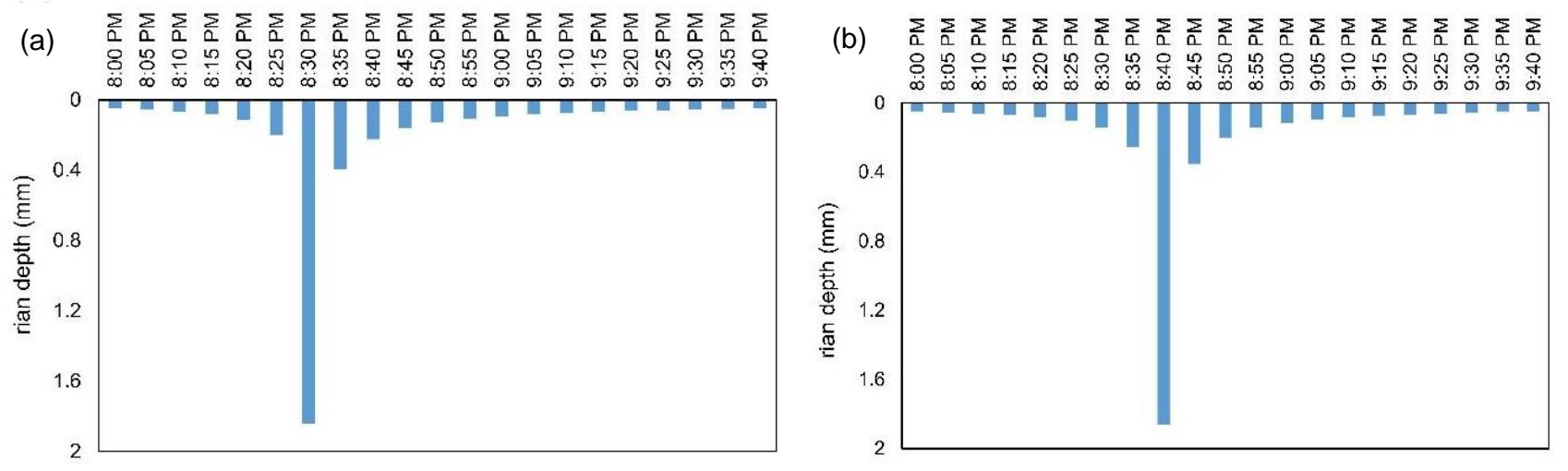

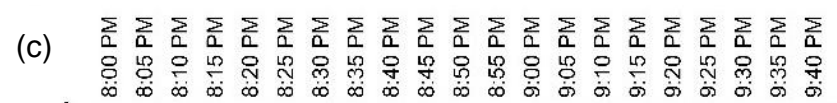

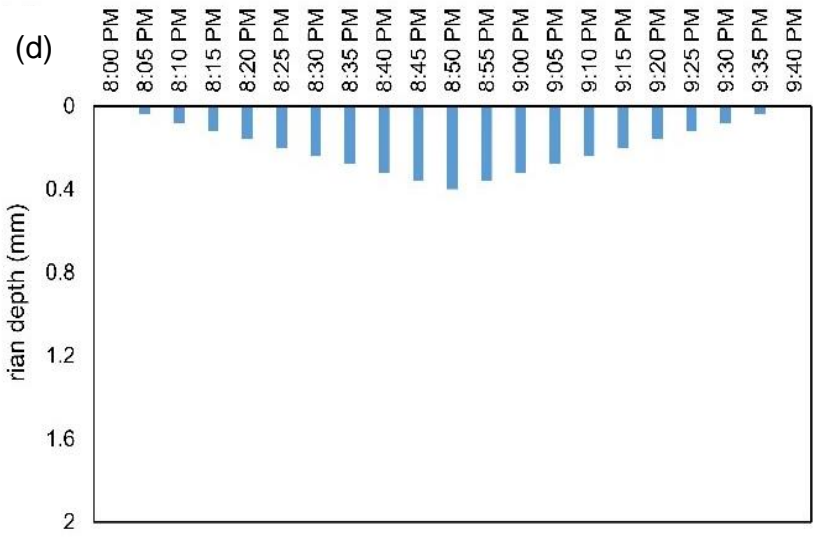

Figure 9. Synthetic hyetographs to model the storm event on September 20, 2007, (a) Chicago hyetograph Y=0.3; (b) Chicago hyetograph $\mathrm{Y}=0.4$; (c) Chicago hyetograph $\mathrm{Y}=0.5$; (d) triangular hyetograph.
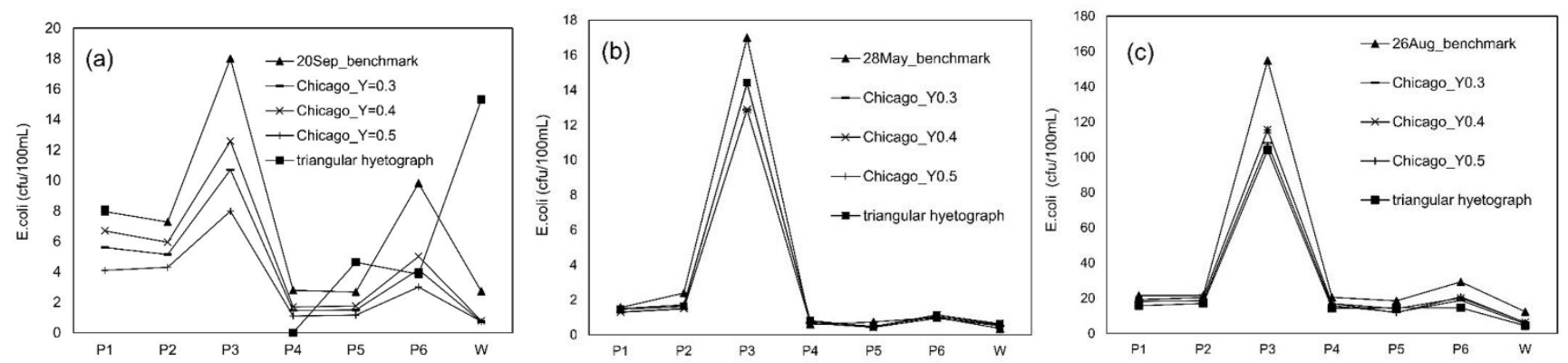

Figure 10. Impact of hyetograph on bacteria distribution after the event occurred on (a) September 20, 2007; (b) May 28, 2007; and (c) August 26, 2007. The ' $\mathrm{W}$ ' on the horizontal axis refers to the withdrawal location.
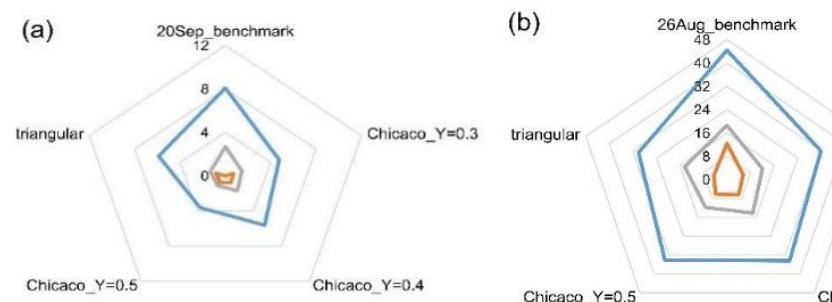

Chicaco_ $Y=0.5$
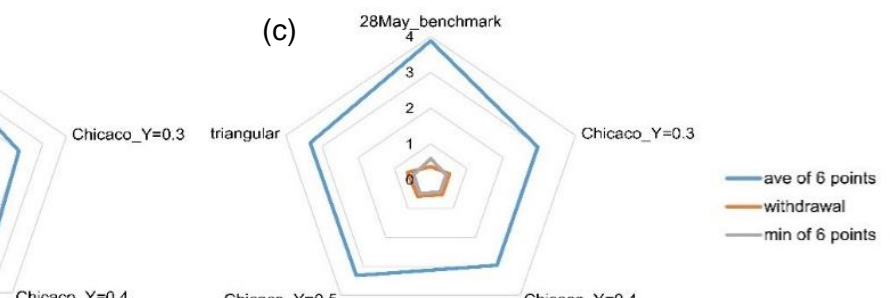

Figure 11. Impact of hyetograph on the bacteria distribution at the withdrawal location after the event on (a) September 20, 2007; (b) August 26, 2007; and (c) May 28, 2007. 

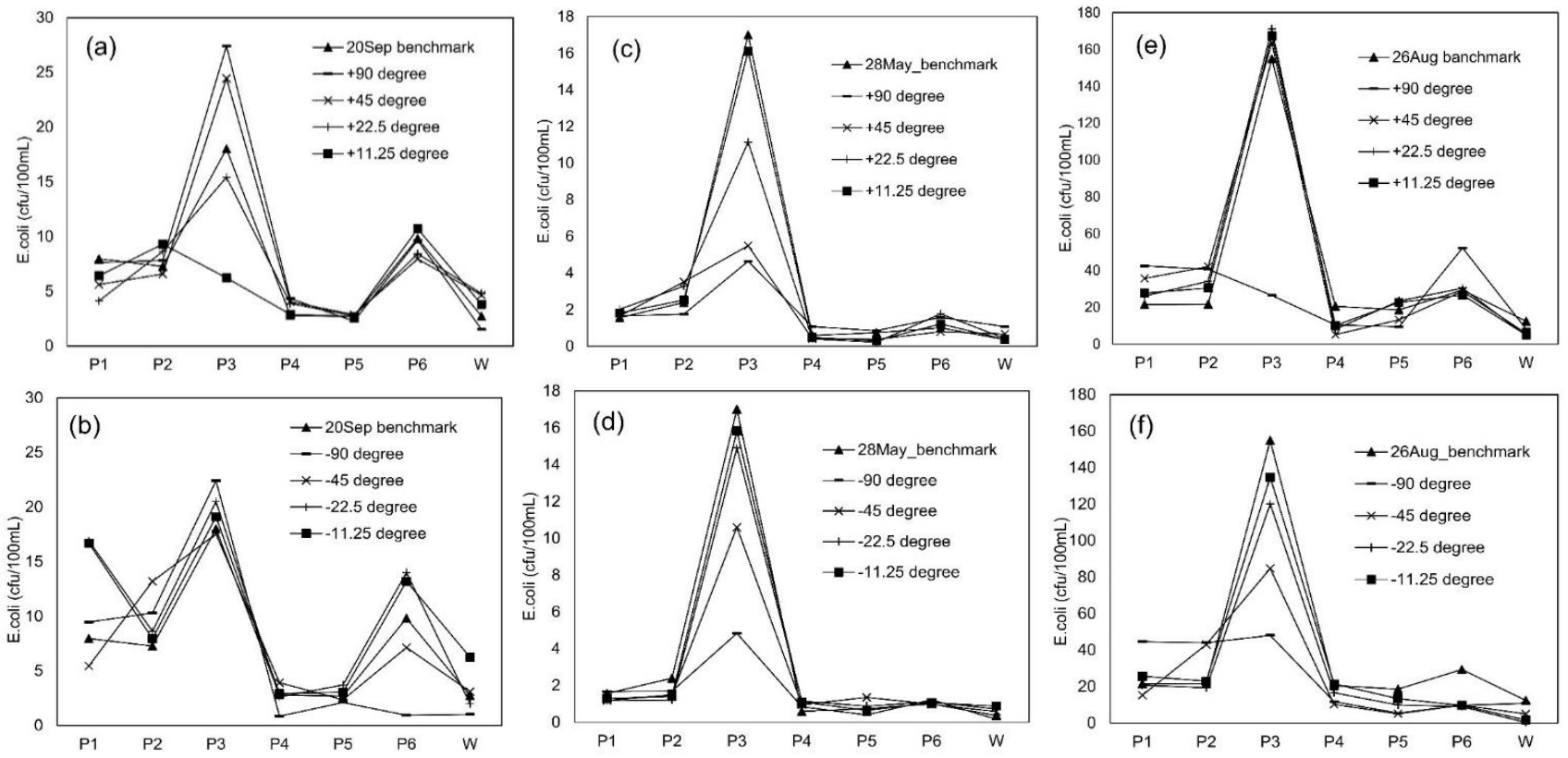

Figure 12. Impact of wind direction on bacteria distribution after the event on (a) and (b) September 20, 2007; (c) and (d) May 28, 2007; (e) and (f) August 26, 2007. The 'W' on the horizontal axis refers to the withdrawal location.

Figure also confirms that the withdrawal location would still be the optimal location for water withdrawal for reuse because it would have the lowest bacteria concentration. It can be concluded that synthetic hyetographs, particularly the Chicago hyetograph, can be used to find the most contaminated and the optimal withdrawal location of a stormwater pond for design purposes or when actual rain data is not available.

\subsubsection{Impact of Wind Direction}

A set of simulations was run to study the effect of wind direction on the bacteria distribution of the pond. Accordingly, all other parameters such as rain hyetograph, bacteria concentration in the inlets and wind magnitude were the same as those of the actual event. It should be noted that the wind data (magnitude and direction) at the time was recorded on an hourly basis. For studying the impact of wind direction, the actual wind data, in which wind direction and magnitude change hourly, was modified and used for the simulations. The direction is basically an angle, and constant values were added or subtracted to it. In this paper the wind directions are handled on a trigonometric basis. For example, adding 90 degrees to a North wind would turn it into a West wind. Figure 12 shows the bacteria distribution after the three events if the wind is rotated by certain angles. The wind was rotated from -90 to +90 degrees with smaller intervals at the middle of the range. Figures 12(a) shows that if the direction of wind at the event on September 20, 2007 was changed, in most cases the pattern of the bacteria distribution 24 hours after the event (bacteria concentration from P1 to P6) would generally follow the pattern of the BOC. In other words, $\mathrm{P} 3$ experienced the maximum concentration of bacteria and P6 in the South wing was the next highly contaminated location. However, Figure 12(b) shows that the pattern was not followed in three out of four cases. To be specific, in the $-90^{\circ}$ case, the bacteria concentration at P6 was the lowest among all the locations. Also, in the $-22.5^{\circ}$ and $-11.25^{\circ}$ cases, concentration of P1 was larger than that of P6. The bacteria distribution after the event occurred on May 28, 2007 changed substantially with the change in wind direction, but it generally followed the pattern of the BOC (see Figures 12(c) and 12(d)). Also, the change in the bacteria distribution itself followed a pattern after the event occurred May 28, 2020. That is, with increasing the change in the wind direction the change in bacteria concentration at P3, the most contaminated location, increased with the maximum and minimum changes occurred in $90^{\circ}$ and $11.25^{\circ}$ change, respectively. The bacteria distribution after the event on August 26, 2007 had some exceptions that did not follow the pattern, see Figures 12(e) and 12(f). For example, in the $+90^{\circ}$ case, P3 was not the most contaminated case anymore. Also, in the $-90^{\circ}$ case, P6 located at the South wing was not the second most contaminated location. However, Figure 12(f) shows a pattern in the bacteria distribution at P3. In general, Figure 12 shows that study of wind direction is both event specific and location specific and it is not practical to make a general prediction about the impact of wind direction on the bacteria distribution throughout the pond. The reason is that the shape of the pond and the high number of inlets make it difficult to predict the fluid flow, which is 3-dimensional and unsteady. Also, the wind is changing over time.

However, studying the impact of wind direction more closely on the withdrawal location shows that by changing wind direction, the withdrawal location might not be the optimal location anymore. The reason is that in some cases the bacteria concentration in the other locations happened to be lower than that of withdrawal location. Interestingly, some of those cases occurred when the wind direction changed slightly as seen in 

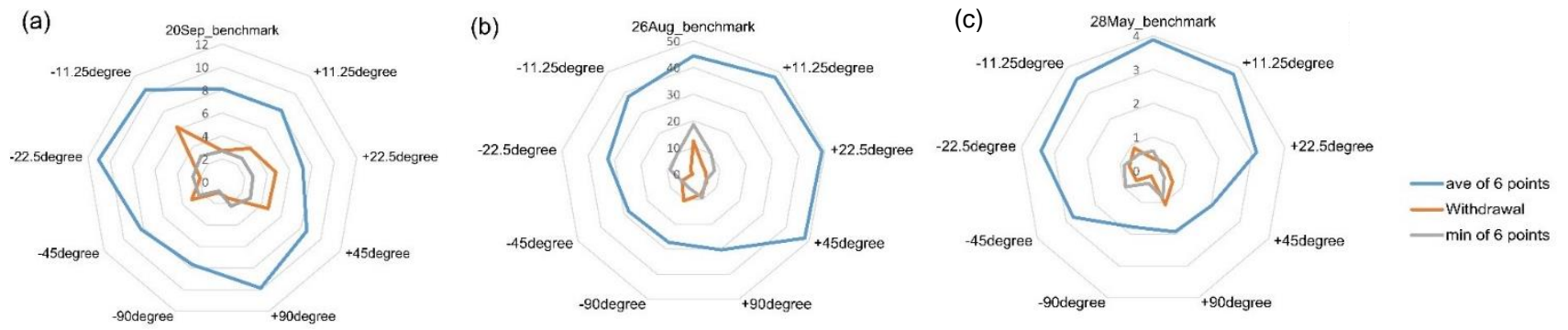

Figure 13. Impact of wind direction on the bacteria distribution at the withdrawal location after the event on (a) September 20, 2007; (b) August 26, 2007; and (c) May 28, 2007.
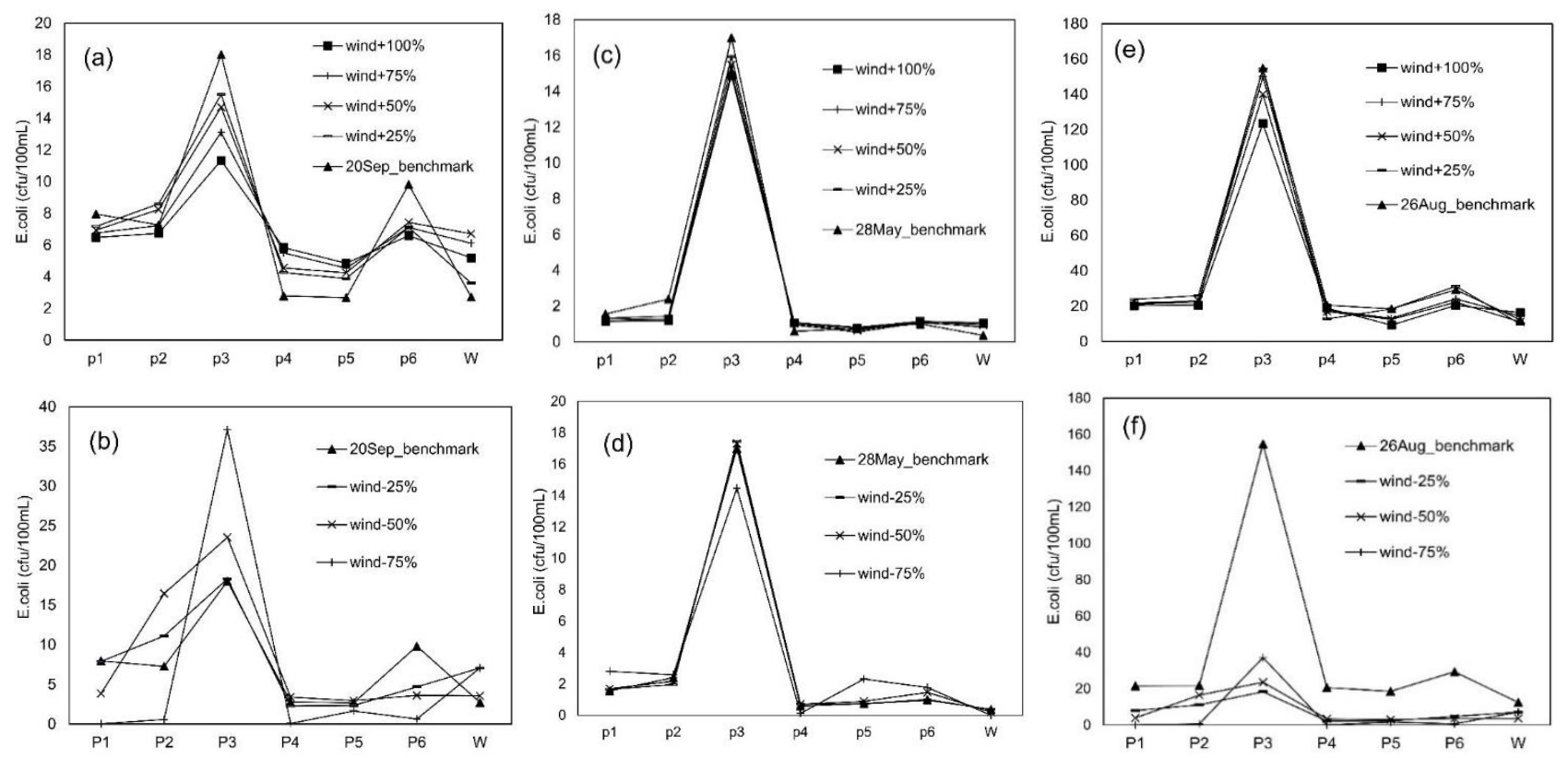

Figure 14. Impact of wind magnitude on bacteria distribution after the events occurred on (a) and (b) September 20, 2007; (c) and (d) May 28, 2007; (e) and (f) August 26, 2007. The 'W' on the horizontal axis refers to the withdrawal location.

Figure 13. It should be noted that the bacteria concentration at the withdrawal location remained below that of the average of the six locations in all of the cases regarding the change in wind direction. Both Figures 13 and 11 show the impact of an environmental factor, namely wind direction and rain, respectively, on the bacteria distribution of the withdrawal location and compared with that of other locations. Therefore, despite the difference in the nature of those environmental factors, comparing the figures might enable us to assess the relative importance of different environmental factors. Originally the withdrawal location had been determined because it was the optimal location for withdrawal for reuse. In other words, it had shown the lowest bacteria concentration throughout and after the events. The withdrawal location remained optimal with different rain hyetographs (see Figure 11). However, it was not optimal location anymore in several cases when the wind direction changed, (see Figure 13). This might indicate a larger impact of wind direction on bacteria distribution, particularly in the withdrawal location, than rainfall distribution. However, due to the difference in the nature of the environmental factors and their impact on the total number of bacteria in the pond, greater study is recommended.

\subsubsection{Impact of Wind Magnitude}

Similar to the wind direction, wind magnitude during and after the events was changing on an hourly basis. In this section, the impact of wind magnitude on bacteria distribution is studied by changing the hourly wind magnitude data points. For example, simulating the pond with a wind magnitude half of the wind in actual event shows the bacteria distribution if the wind would have been half of what it was, denoted by wind-50\% in Figure 14. In all of the three events, when the wind magnitude increased, the bacteria concentration pattern from P1 to P6 was generally followed. In addition, it can be observed that increasing wind magnitude caused an underestimation in bacteria concentration at $\mathrm{P} 3$, the most contaminated location of the pond. The reason is that P3 is located at the tip of the West wing and the highly contaminated stormwater entered the pond from the nearby subbasins has only one way to get transported to the other parts of the pond. In the process of transporting bacteria from 

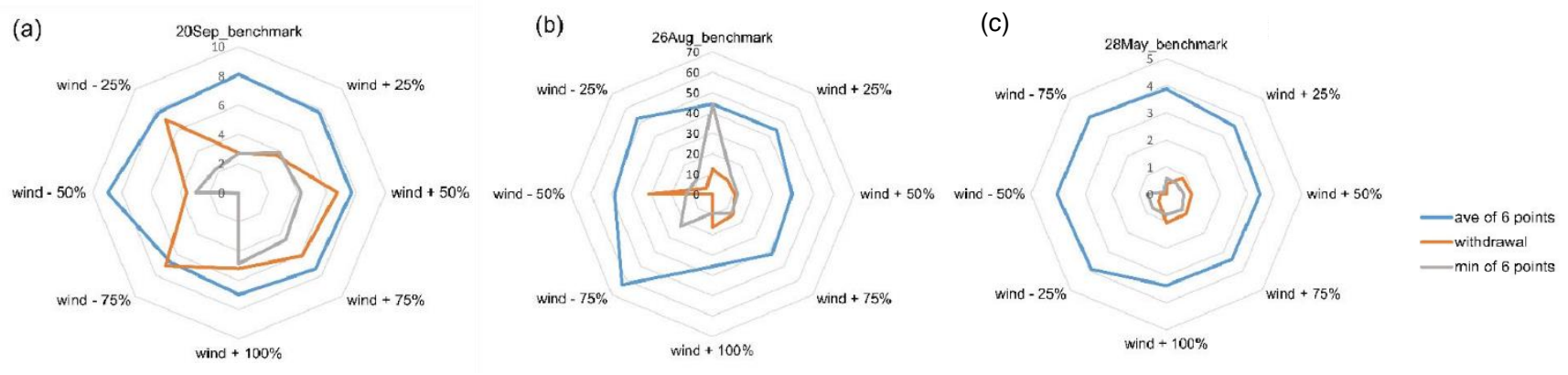

Figure 15. Bacteria concentration at the Withdrawal location on (a) September 20, 2007; (b) August 26, 2007; and (c) May 28, 2007.
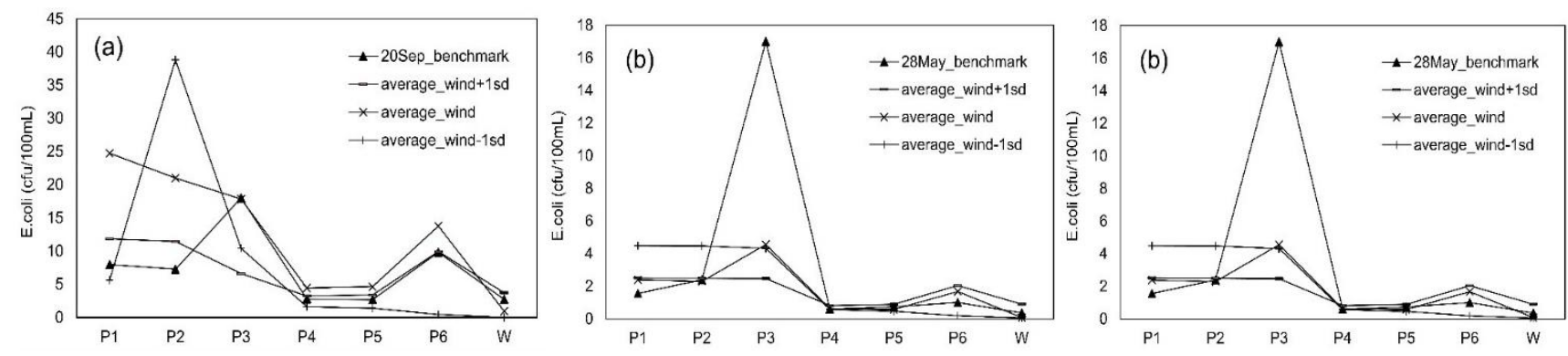

Figure 16. Impact of averaged wind on the bacteria distribution in the pond on (a) September 20, 2007; (b) May 28, 2007; (c) August 26, 2007. The ' $W$ ' on the horizontal axis refers to the withdrawal location.

this location to the rest of the pond, wind plays the primary role. Therefore, increasing the wind magnitude accelerated transportation of highly contaminated stormwater from this region, and thus, the bacteria concentration dropped in this area. The maximum drop occurred in the case of doubling the wind (wind+ $100 \%)$ after all of the three events. However, decreasing the wind magnitude during and after the actual events does not necessarily decrease or increase the bacteria concentration at P3. In addition, the pattern of bacteria concentration from P1 to P6 was not followed in the cases that wind magnitude was lower than that of actual events, see Figures 14(b), 14(d), and 14(f). The effect of diffusion of bacteria in the transportation of bacteria was assumed to be negligible compared to that of convection in the model. The effect of diffusion on the transport is more highlighted when the wind magnitude is minimal. Therefore, decreasing wind will increase spatial sensitivity of the model because the main factor that played role in distributing bacteria was decreased, and thus, the gradient of bacteria concentration near the inlets increases. In other words, the contaminated stormwater that was discharged into the pond during the storm would not get dispersed and would remain as a plug that moves slowly. Then, if the grab sampling location (P1 P6) and withdrawal location happen to be near the periphery of the plug, the high sensitivity of the model would appear in the bacteria concentration. This effect can be observed in Figures 14(b), 14(d), and 14(f).

\subsubsection{Impact of Averaged Wind}

In an attempt to further assess the predictability of the bacteria distribution in the pond, the averaged wind during the irri- gation season was obtained and the pond was simulated with that wind. The wind magnitude in Calgary, which has been recorded since 1971 on an hourly basis (Canada Weather Stats, 2020), was averaged for irrigation seasons (beginning of May to the end of September). Similarly, hourly wind direction data has been recorded since 2014, and it was averaged as well. The averaged wind magnitude and direction in irrigation season were found to be $14.5 \mathrm{~km} / \mathrm{h}$ and $178^{\circ}$ angle, respectively. The pond was simulated with that wind and the modeled bacteria distribution was compared with that of the actual event. Moreover, the pond was simulated with two other wind magnitudes equal to the averaged wind \pm 1 standard deviation of the wind. The pond was simulated with a constant wind, in which neither wind magnitude nor wind direction changes. Other inputs and parameters, such as inflow flowrates and bacteria pollute-graphs of the inlets, remained the same as those of the actual event. Figure 16 shows the bacteria distribution at the six grab sampling locations considering the averaged wind. None of the cases corresponding to September 20, 2007 nor August 26, 2007 followed the bacteria concentration pattern of the actual event, and only one case corresponding to May 28, 2007 followed the pattern. In addition, the difference between the bacteria concentration corresponding to the actual event and that of the averaged wind was relatively high. Therefore, predicting the bacteria distribution with a constant wind is not considered practical.

The modeled concentration of bacteria in the withdrawal location after the three actual events were compared with that of stronger and weaker wind. Figure 15 shows the comparison. The modeled bacteria concentration at the withdrawal location in all of cases was lower than the average of that of the six locations. However, in most of the cases the concentration in the 
withdrawal location was higher than the minimum of the six locations. Therefore, the withdrawal was not the optimal location anymore. This might indicate the large impact of wind magnitude on the bacteria distribution in the pond.

\section{Conclusions}

The integrated hydrological and CFD model (IHCFD), which was initially developed to simulate bacteria fate and transport in the Inverness stormwater pond, Calgary, AB, Canada for the purposes of reusing the stormwater, was further modified, verified and studied for sensitivity in this work. The model was verified for both fluid flow and bacteria distribution against the data collected from the pond. The fluid flow verification was performed for a wind driven flow, and good agreement was observed. The bacteria distribution data showed some parts of the pond became more contaminated between 2007 and 2017; however, the tip of the west wing was found to be the most contaminated location of the pond. The model results showed a good agreement with the collected data. Once verified, the impact of the model's assumptions on output were assessed using a sensitivity analysis. IHCFD was run a copious number of times to assess the impacts of different inputs on the bacteria distribution in the pond. The impacts were more closely studied for the withdrawal location, which was determined as the optimal location for pulling stormwater from the pond for later reuse. The particle size that E.coli predominantly attach to was one of the assumptions studied and it was found that increasing particle size generally decreases the bacteria concentration in the grab sampling locations due to the settling. However, no noticeable difference was found in the bacteria distribution at the study locations when the attached particle size was increased from 10 $\sim 20 \mu \mathrm{m}$ to $20 \sim 50 \mu \mathrm{m}$. Attachment rate was also studied and it was found that with non-settling sediment, the bacteria concentration decreases in all study locations with decreasing the attachment rate. However, with settling-sediment this decrease only occurred at the most contaminated location. The impact of rainfall distribution was also assessed by comparing bacteria distribution in the pond arising from 4 different synthetic rainfall distributions with that produced by the actual rain. It was found that for design purposes or if there is a lack of collected data, synthetic hyetographs could be used to determine pond hot spots - locations with the highest level of contamination as well as the optimal location for withdrawal. In addition, the model was run for several wind directions and wind magnitudes. Results revealed that the impact of wind direction is event specific and location specific. Changes in wind magnitude resulted in changes to the optimal withdrawal. In general, wind was found to play a critical role in the bacteria distribution of the pond.

Acknowledgments. The Authors would like to thank the reviewers for taking the time to review this paper and for their insightful comments. The authors would also like to thank Dr. Angus Chu and Dr. David Bethune of the University of Calgary for their assistance in data collection. The Authors gratefully acknowledge Alberta Innovates for funding this research, grant number RES\#0030866, and the National Research Council of Canada (grant number CRDPJ 520869 - 17).

\section{References}

Abbasi, A., Annor, F.O., and van de Giesen, N. (2016). Investigation of temperature dynamics in small and shallow reservoirs. Case study: Lake Binaba, upper east region of Ghana. Water. 8(3), 1-24. https://doi.org/10.3390/w8030084

Aguilera, R., Sabater, S., and Marce, R. (2016). A methodological framework for characterizing the spatiotemporal variability of river water-quality patterns using dynamic factor analysis, Journal of Environmental Informatics, 32(2). https://doi.org/10.3808/jei.2016 00333

Allafchi, F., Valeo, C., Chu, A., He, J., Lee, W., Oshkai, P., and Neumann, N.F. (2020). A velocity meter for quantifying fluid flow velocity vectors in large water bodies. Sensors 20(24), 7204. https: //doi.org/ 10.3390/s20247204

Allafchi, F., Valeo, C., He, J., and Neumann, N.F. (2021). A mechanistic model for estimating bacteria level in stormwater ponds. Journal of Hydro-environment Research https://doi.org/10.1016/j. jher.2021.06.002

Allafchi, F., Valeo, C., He, J., and Neumann, N.F. (2019). An integrated hydrological-CFD model for estimating bacterial levels in stormwater ponds. Water 11(5), 1016. https://doi.org/10.3390/w1 1051016

American Institute of Iron and Steel. (2010). Handbook Of Steel Drainage \& Highway Construction Products. Second Canadian edition.

Anna, H., Jeng, C., Englande, A.J., Bakeer, R.M., and Bradford, H.B. (2005). Impact of urban stormwater runoff on estuarine environmental quality. Estuarine, Coastal and Shelf Science 63 513-26. https://doi.org/10.1016/j.ecss.2004.11.024

Babaeyan-Koopaei, K., Ervine, D. A. and Pender, G. (2003). Field Measurements and flow modeling of overbank flows in River Severn, U.K., Journal of Environmental Informatics, 1(1), 28-36, https://doi.org/10.3808/jei.200300004

Bai, S. and Lung, W.S. (2005). Modeling sediment impact on the transport of fecal bacteria. Water Research, 39(20), 5232-40. https:// doi.org/10.1016/j.watres.2005.10.013

Beaudeau, P., Tousset, N., Bruchon, F., Lefèvre, A., and Taylor, H.D. (2001). In situ measurement and statistical modelling of Escherichia Coli decay in small rivers. Water Research, 35(13), 3168-3178. https://doi.org/10.1016/S0043-1354(01)00011-2

Borrego, J.J. and Figueras, M.J. (1997). Microbiological quality of natural waters. Microbiologia, 13 413-26.

Canada Weather Stats. (2020). www.weatherstats.ca.

De Brauwere, A., Gourgue, O., de Brye, B., Servais, P., Ouattara, N.K., and Deleersnijder, E. (2014a). Integrated modelling of faecal contamination in a densely populated river-sea continuum (Scheldt River and Estuary). Science of the Total Environment, 468, 31-45. https://doi.org/10.1016/j.scitotenv.2013.08.019

De Brauwere, A., Ouattara, N.K., and Servais, P. (2014b). Modeling fecal indicator bacteria concentrations in natural surface waters: A review. Critical Reviews in Environmental Science and Technology, 44(21), 2380-2453. https://doi.org/10.1080/10643389.2013.829978

Ellouze, M., Abida, H., Safi, R., Ellouze, M., Abida, H., and Safi, R. (2009). A triangular model for the generation of synthetic hyetographs. Hydrological Sciences Journal, 6667, 287-99. https://doi. org/10.1623/ hysj.54.2.287

Flow Science, I. (2018). FLOW-3D v11.2 User Manual.

Foreman, R.J. and Emeis, S. (2010). Revisiting the definition of the drag coefficient in the marine atmospheric boundary layer. Journal of Physical Oceanography, 40, 2325-32. https://doi.org/10.1175/20 10JPO4420.1

Goonetilleke, A., Liu, A., Managi, S., Wilson, C., Gardner, T., Bandala, E.R., Walker, L., Holden, J., Wibowo, M.A., Suripin, S., Joshi, H., Bonotto, D.M., and Rajapaksa, D. (2017). Stormwater reuse, a 
viable option: Fact or fiction? Economic Analysis and Policy, 56. 14-17. https://doi.org/10.1016/j.eap.2017.08.001

Hammes, G., Thives, L.P., and Ghisi, E. (2018). Application of stormwater collected from porous asphalt pavements for nonpotable uses in buildings. Journal of Environmental Management, 222, 338 47. https://doi.org/10.1016/j.jenvman.2018.05.094

He, J., Valeo, C., and Chu, A. (2015). Variation in water quality of a stormwater pond from diurnal thermal stratification. Journal of Water Resource and Hydraulic Engineering, 4(1-2), 189-198. https: //doi.org/ 10.5963/JWRHE0402008

He, J., Valeo, C., Chu, A. and Neumann, N. (2011a). Prediction of event-based stormwater runoff quantity and quality by ANNs developed using PMI-based input selection. Journal of Hydrology, 400 (1-2), 10-23. https://doi.org/10.1016/j.jhydrol.2011.01.024

He, J., Valeo, C., Chu, A., and Neumann, N.F. (2011b). Stormwater quantity and quality response to climate change using artificial neural networks. Hydrological Processes, 25 1298-1312. https://doi. org/10.1002/hyp.7904

He, J., Valeo, C., Chu, A. and Neumann, N. (2010a). Microbiological, physical and chemical water quality of event-based stormwater runoff from an urban residential area. Water Environmental Research, 82 (12), 2333-2345. https://doi.org/10.2175/106143010X12681059 117058

He, J., Valeo, C., Chu, A. and Neumann, N. (2010b). Characterizing physicochemical quality of stormwater runoff from an urban area in Calgary, Alberta. Journal of Environmental Engineering, 136(11), 12061217. https://doi.org/10.1061/(ASCE)EE.1943-7870.0000267

He, J., Valeo, C., Chu, A., and Neumann, N.F. (2008). Water quality assessment in the application of stormwater reuse for irrigating public lands. Water Quality Research Journal of Canada, 43(2), 93107. https://doi.org/10.2166/wqrj.2008.018

Hirt, C.W. and Nichols, B.D. (1981). Volume of fluid (VOF) method for the dynamics of free boundaries. Journal of Computational Physics, 39, 201-25. https://doi.org/10.1016/0021-9991(81)90145-5

Mankad, A., Walton, A., and Gardner, J. (2019). Psychological predictors of public acceptance for urban stormwater reuse. Journal of Hydrology, 572, 414-21. https://doi.org/10.1016/j.jhydrol.2019. 03.018

Muirhead, R.W., Collins, R.P., and Bremer, P.J. (2006). Interaction of Escherichia Coli and soil particles in runoff. Applied and Environmental Microbiology, 72(5), 3406-11. https://doi.org/10.1128/AEM. 72.5.3406-3411.2006

National Academies of Sciences and Medicine, E. (2016). Using Graywater and Stormwater to Enhance Local Water Supplies: An Assessment of Risks, Costs, and Benefits. National Academies Press.

Ouattara, N.K., de Brauwere, A., Billen, G., and Servais, P. (2013). Modelling faecal contamination in the Scheldt drainage network. Journal of Marine Systems, 128 77-88. https://doi.org/10.1016/j.j marsys. 2012.05.004

Rodríguez-sinobas, L., Zubelzu, S., Perales-momparler, S., and Canogar, S. (2018). Techniques and criteria for sustainable urban stormwater management. The case study of Valdebebas (Madrid, Spain). Journal of Cleaner Production, 172. 402-16. https://doi.org/10.101 6/j.jclepro. 2017.10.070

Savage, B.M. and Johnson, M.C. (2001). Flow over ogee spillway: Physical and numerical model case study. Journal of Hydraulic Engineering, 127(8), 640-49. https://doi.org/10.1061/(ASCE)07339429

Schoonover, J.E. and Lockaby, B.G. (2006). Land cover impacts on stream nutrients and fecal coliform in the lower piedmont of west Georgia. Journal of Hydrology, 331 371-82. https://doi.org/10.101 6/j. jhydrol.2006.05.031
Shilton, A. (2000). Potential application of computational fluid dynamics to pond design. Water Science and Technology, 42(10-11), 327-34. https://doi.org/10.2166/wst.2000.0673

Shilton, A. and Harrison, J. (2003). Integration of coliform decay within a CFD (Computational Fluid Dynamic) model of a waste stabilisation pond. Water Science and Technology, 45(2), 205-10. https:// doi.org/10.2166/wst.2003.0122

Shilton, A.N. and Mara, D.D. (2005). CFD (Computational Fluid Dynamics) modelling of baffles for optimizing tropical waste stabilization pond systems. Water Science and Technology, 51(12), 103-6. https://doi.org/10.2166/wst.2005.0438

Shilton, A., Kreegher, S., and Grigg, N. (2008). Comparison of computation fluid dynamics simulation against tracer data from a scale model and full-sized waste stabilization pond. Journal of Environmental Engineering, 134, 845-50. https://doi.org/10.1061/(ASCE)0 733-9372(2008)134:10(845)

Shrestha, N.K. and Wang, J. (2019). Water quality management of a cold climate region watershed in changing climate, Journal of Environmental Informatics, 35(1), 56-80, https://doi.org/10.3808/ jei.201900407

Soulsby, R. (1997). Dynamics of Marine Sands A Manual for Practical Applications. 1st ed. Thomas Telford Services Ltd.

Tallon, P., Magajna, B., Lofranco, C., and Leung, K.T. (2005). Microbial indicators of faecal contamination in water: A current perspective. Water, Air, and Soil Pollution, 166, 139-66. https://doi.org/10. 1007/s 11270-005-7905-4

The City of Calgary Water Resources. (2011). Stormwater Management and Design Manual. http://www.calgary.ca/UEP/\% 0AWater/Pages/Water-and-wastewater-systems/Stormdrainagesys tem/\%0AHistory.aspx.

U.S. Army Corps of Engineers. (2016) Hydrological Modeling System HECHMS, User's manual.

Vanaei, A., Guo, X., Wu, P., Richter, A., and Ng, K.T.W. (2021). Numerical simulation of water quality and self-purification in a mountainous river using QUAL2KW, Journal of Environmental Informatics, 37(1), https://doi.org/10.3808/jei.202000435

Vergeynst, L., Vallet, B., Vanrolleghem, P. (2012). Modelling pathogen fate in stormwaters by a particle-pathogen interaction model using population balances. Water Science and Technology, 65(5), 823-32. https://doi.org/10.2166/wst.2012.818

Wang, Y., Pandey, P., Zheng, Y., Atwill, E.R., and Pasternack, G. (2018). Particle Attached and Free Floating Pathogens Survival Kinetics under Typical Stream and Thermal Spring Temperature Conditions. AMB Express 8(100). https://doi.org/10.1186/s13568018-0626-z

Wu, B. and Chen, Z. (2011). An integrated physical and biological model for anaerobic lagoons. Bioresource Technology, 102, 503238. https://doi.org/10.1016/j.biortech.2011.01.076

Wu, J., Rees, P., Storrer, S., Alderisio, K., and Dorner, S. (2009). Fate and transport modeling of potential pathogens: the contribution from sediments. Journal of the American Water Resources Association, 45(1), 35-44. https://doi.org/10.1111/j.1752-1688.2008.0028 7.x

Zhang, K., Randelovic, A., Aguiar, L.M., Page, D., McCarthy, D.T., and Deletic, A. (2015). Methodologies for pre-validation of biofilters and wetlands for stormwater treatment. PLoS One, 10(5), 121. https://doi.org/10.1371/journal.pone.0125979

Zheng, C., Yang, W., and Yang, Z.F. (2011). Strategies for managing environmental flows based on the spatial distribution of water quality: A case study of Baiyangdian Lake, China, Journal of Environmental Informatics, 18(2), 84-90. https://doi.org/10.3808/jei.20 1100202 